\title{
Regulation of gene expression in Sertoli cells by follicle-stimulating hormone (FSH): cloning and characterization of $L R P R 1$, a primary response gene encoding a leucine-rich protein
}

\author{
K.E. Slegtenhorst-Eegdeman*, M. Post, W.M. Baarends, A.P.N. Themmen, J.A. Grootegoed \\ Department of Endocrinology and Reproduction, Faculty of Medicine and Health Sciences, Erasmus University Rotterdam, P.O. Box 1738, 3000 DR \\ Rotterdam, The Netherlands
}

Received 21 October 1994; accepted 9 December 1994

\begin{abstract}
Searching for hormone-regulated genes in testicular Sertoli cells, we cloned and sequenced a cDNA of 3108 base pairs, named LRPRI (signifying leucine-rich primary response gene 1). This cDNA sequence has an open reading frame of 2238 base pairs encoding a leucine-rich protein of 746 amino acid residues with a relative molecular mass of $85.6 \mathrm{kDa}$. As much as $16 \%$ of the amino acid residues is leucine. Database analysis revealed significant similarity of LRPR1 to the human brain cDNA sequence EST00443, but not to any other sequences present in databases. The expression of LRPRI mRNA in Sertoli cells is strongly and rapidly up-regulated by follicle-stimulating hormone (FSH). The level of LRPRI mRNA was very low in Sertoli cells isolated from 21-day-old rats and cultured for 3 days in the absence of FSH, but LRPRI mRNA expression was markedly increased within $2 \mathrm{~h}$ after addition of FSH to these cultures. A maximal response was reached within $4 \mathrm{~h}$. Dibutyryl-cyclic AMP [(Bu) $\left.{ }_{2} \mathrm{cAMP}\right]$ and forskolin had similar effects compared to FSH, indicating that cAMP acts as a second messenger in the regulation of $L R P R I$ expression. The up-regulation of $L R P R I$ mRNA expression by FSH was also observed in the presence of the protein synthesis inhibitor cycloheximide, indicating that FSH regulates $L R P R I \mathrm{mRNA}$ expression through a direct mechanism which does not require de novo protein synthesis. Thus, $L R P R I$ represents a primary response gene in FSH action on Sertoli cells. The presently available data indicate that $L R P R I$ mRNA expression is regulated specifically by FSH, since several other hormones and growth factors did not affect $L R P R I$ mRNA expression in the cultured Sertoli cells. LRPRI mRNA expression is relatively high in testis, ovary and spleen. A much lower mRNA level was found in brain and lung, and no expression was detected in liver, kidney, heart, muscle, pituitary gland, prostate, epididymis and seminal vesicle. The basal level of testicular LRPRI expression in intact 21-day-old rats was markedly increased within several hours after a single i.p. injection of FSH, indicating that in vivo LRPRI mRNA expression may appear to be a useful parameter to evaluate testicular FSH action.
\end{abstract}

Keywords: Follicle-stimulating hormone; Sertoli cells; Spermatogenesis; Testis

\section{Introduction}

Follicle-stimulating hormone (FSH) from the pituitary gland and testosterone from testicular Leydig cells are generally considered to be the main regulators of spermatogenesis. FSH is thought to play a major role in the initiation of spermatogenesis in immature mammals, but is also involved in quantitative and qualitative maintenance of spermatogenesis in adult animals, in particular in primates (Clermont and Harvey, 1967; Steinberger, 1971;

\footnotetext{
${ }^{*}$ Corresponding author, Fax: +31104366832.
}

Hansson et al., 1975a; Means et al., 1976; Marshall et al., 1986; Moudgal et al., 1992). This is supported by the observation that experimental immunization of male bonnet monkeys to ovine-FSH resulted in reversible infertility (Moudgal et al., 1992). This infertility involved a decreased number of spermatozoa in the ejaculate, but also a reduced fertilizing capacity of the remaining spermatozoa (Moudgal et al., 1992).

The long-term effect of FSH on Sertoli cells may concern the maturation and maintenance of differentiated properties of these cells. This action of FSH includes protein phosphorylation and regulation of the synthesis of 
many proteins such as androgen-binding protein (Dorrington et al., 1975; Hagenas et al., 1975; Hansson et al., 1975b), transferrin (Huggenvik et al., 1987), tissue type plasminogen activator (Bardin et al., 1994; Nargolwalla et al., 1990), steel factor (Rossi et al., 1993), $\alpha$-inhibin (Toebosch et al., 1988; Klaij et al., 1990) and c-fos (Hall et al., 1988).

With respect to the kinetics of the stimulation of protein synthesis in Sertoli cells by FSH, both slow and rapid responses are found. FSH-induced stimulation of androgen-binding protein production (Dorrington et al., 1975; Hagenas et al., 1975; Hansson et al., 1975b) and transferrin (Huggenvik et al., 1987) by Sertoli cells is a slow process which takes many hours to reach its maximum. Several other responses of Sertoli cells to FSH are much more rapid. These include the effect of FSH on the transcription of the genes encoding tissue type plasminogen activator (Bardin et al., 1994; Nargolwalla., 1990) and $\alpha$ inhibin (Toebosch et al., 1988; Klaij et al., 1990). Within 1-2 $\mathrm{h}$ of stimulation of cultured Sertoli cells with FSH, mRNA expression levels for these genes have already significantly increased, and it takes approximately $6 \mathrm{~h}$ of FSH exposure to obtain maximal effects. One of the most rapid responses of cultured Sertoli cells to FSH is the induction of c-fos mRNA expression (Hall et al., 1988). The c-fos gene, and also the $\alpha$-inhibin gene, show a primary response to FSH, which implies that de novo protein synthesis is not required for stimulation of transcription. Such a response may result from activation of preexisting transcription factors through cAMP-dependent protein kinases.

Most, if not all, known Sertoli cell genes that show FSH-regulated transcription and protein synthesis, do not respond specifically to FSH. Reventos et al. (1988) have shown that androgen-binding protein mRNA expression in rat testis is also stimulated by testosterone. Transferrin mRNA expression can be influenced by many hormones and growth factors, including insulin and retinol (Huggenvik et al,, 1987). C-fos and $\alpha$-inhibin mRNA expression in Sertoli cells are also regulated by other factors besides FSH. Both the testicular paracrine factor PModS and fibroblast growth factor (FGF) can regulate c-fos mRNA expression in cultured Sertoli cells (Smith et al., 1989; Norton and Skinner, 1992), whereas $\alpha$-inhibin mRNA expression in vitro is up-regulated when the Sertoli cells are cultured in medium conditioned by early spermatids (Pineau et al., 1990).

To better understand the molecular mechanisms involved in regulation of Sertoli cell development by FSH, more information about key regulatory genes that are responsive to FSH is essential. In the present report we describe the isolation and characterization of a new cDNA, named leucine-rich primary response gene-1 ( $L R P R I)$, that was isolated from a rat Sertoli cell cDNA library. $L R P R I$ mRNA expression is very rapidly upregulated by FSH. Furthermore, $L R P R I$ responds specifi- cally to FSH, and represents a primary response gene in Sertoli cells exposed to FSH.

\section{Materials and methods}

\subsection{Cells}

Sertoli cells were isolated from testes of 21-day-old rats as described previously (Themmen et al., 1991). The cells were cultured for $48 \mathrm{~h}$ in Eagle's minimal essential medium (Cribco BRL, Middlesex, UK), supplemented with antibiotics, non-essential amino acids, and $1 \%$ fetal calf serum (MFM/FCS), at $37^{\circ} \mathrm{C}$ under $5 \% \mathrm{CO}_{2}$ in air in $80 \mathrm{~cm}^{2}$ plastic culture flasks (Costar, Cambridge, USA). Subsequently, the Sertoli cell cultures were exposed for $2 \mathrm{~min}$ to a hypo-osmotic shock by using tenfold diluted MEM in water (Toebosch et al., 1989), followed by incubation for another 24-h period in MEM with $0.1 \%(\mathrm{w} / \mathrm{v})$ bovine serum albumin (fraction V; Sigma, St Louis, MO, USA) (MEM/BSA). Finally, the cells were incubated in MEM/BSA for different time periods with ovine-FSHS16 (NIH, Bethesda, MD, USA), dibutyryl-cyclic AMP $\left((\mathrm{Bu})_{2} \mathrm{cAMP}\right.$ ), forskolin (Boehringer, Mannheim, Germany), insulin-like growth factor-I (IGF-I) (kind gift from Dr. J. Foekens), insulin (Sigma), R1881 (Nen, Boston, MA, USA), 4 $\beta$-phorbol-12-myristate-13-acetate (PMA) (Sigma), 4 $\beta$-phorbolmonoacetate (PA) (Sigma), actinomycin D (Boehringer) or cycloheximide (Sigma). The efficiency of actinomycin $D$ and cycloheximide treatment on Sertoli cells has been determined previously by measuring $\left[{ }^{3} \mathrm{H}\right]$ uridine and $\left[{ }^{14} \mathrm{C}\right]$ leucine incorporation in the presence or absence of the inhibitor (Klaij et al., 1990). Actinomycin D and cycloheximide inhibited RNA synthesis by $98 \pm 1 \%$ and protein synthesis by $96 \pm 2 \%$, respectively.

To determine in vivo FSH effects on LRPRI mRNA expression, 21-day-old rats were injected i.p. with $1 \mu \mathrm{g}$ ovine FSH-S16 per gram body weight. After different time periods the rats were sacrificed, and total testicular RNA was isolated. All animal care was performed in accordance with the NIH Guide for the Care and Use of Laboratory Animals.

\subsection{RNA}

Isolation of RNA from Sertoli cells and total tissue was performed as described by Auffray and Rougeon (1980). For Northern blotting, RNA was separated in $1 \%(\mathrm{w} / \mathrm{v})$ agarose/formaldehyde gels, and blotted on Hybond $\mathrm{N}^{+}$ nylon membrane filters (Amersham, Buckinghamshire, UK). The blots were hybridized overnight at $42^{\circ} \mathrm{C}$ with ${ }^{32}$ P-labelled $L R P R I$ cDNA probe in $50 \%(\mathrm{v} / \mathrm{v})$ formamide, $5 \times$ SSC, $5 \times$ Denhardt's, $1 \%(\mathrm{w} / \mathrm{v})$ SDS, $50 \mathrm{mM}$ phosphate buffer ( $\mathrm{pH} 6.8$ ), containing $100 \mu \mathrm{g} / \mathrm{ml}$ herring sperm DNA (Sambrook et al., 1989). After hybridization, the blots were washed to a final stringency of $0.1 \times$ $\mathrm{SSC} / 0.5 \%(\mathrm{w} / \mathrm{v}) \mathrm{SDS}$ at $42^{\circ} \mathrm{C}$, and autoradiography was performed to visualize the bands. 
For the RNase protection assay, a 322 bp BamHI-BgllI fragment containing bp 1769-2091 from LRPR1 was subcloned in pBluescript KS (Stratagene, La Jolla, CA, USA) and used to generate [32P]UTP-labelled anti-sense transcripts in vitro. The control glyceraldehyde 3-phosphate dehydrogenase (GAPDH) RNA probe was synthesized using a construct containing a $310 \mathrm{bp} X h o I$ fragment from rat GAPDH cDNA (Fort et al., 1985). Approximately $5 \times 10^{4} \mathrm{cpm}$ of $L R P R I$ probe was mixed with $5 \mu \mathrm{g}$ of total RNA in a total volume of $30 \mu \mathrm{l}$ hybridization mixture containing $40 \mathrm{mM}$ Pipes ( $\mathrm{pH}$ 6.4), $1 \mathrm{mM}$ EDTA, $0.4 \mathrm{M} \mathrm{NaCl}$ and $80 \%$ (v/v) formamide. The hybridizations were performed overnight at $45^{\circ} \mathrm{C}$. To test if equal amounts of RNA were present, GAPDH was used in a separate RNase protection assay. For $L R P R 1$, one specific 322 bp protected fragment was found. However, some less abundant non-specific bands can also be detected. The RNase protection assay, as well as all general molecular biology techniques were carried out as described by Sambrook et al. (1989). The autoradiograms shown are representative of at least two independent experiments.

\subsection{Cloning of LRPRI}

A Sertoli cell directional cDNA library in pBluescript SK (Stratagene) (Baarends et al., 1994) was screened using a DNA amplification approach with Taq DNA polymerase (Sphaero Q, Leiden, The Netherlands). The strategy of the screening was based on the working hypothesis that primary response genes might encode $\mathrm{C}_{2} \mathrm{H}_{2}$ type zinc finger containing transcription factors. Therefore, the primers were the vector-based reverse M13 sequence primer ( $5^{\prime}$-AACAGCTATGACCATG- $\left.3^{\prime}\right)$ and an antisense degenerate primer based on the connecting amino acid sequence of the $\mathrm{C}_{2} \mathrm{H}_{2}$-type of zinc finger proteins (5'-GCAITCATAIGGITTITCICGIGTGTG-3') (Thiessen, 1990). The primers were annealed for $5 \mathrm{~min}$ at $37^{\circ} \mathrm{C}$, after which two amplification cycles were performed $\left(2 \mathrm{~min}\right.$ synthesis at $72^{\circ} \mathrm{C}, 1 \mathrm{~min}$ denaturation at $95^{\circ} \mathrm{C}$, and $2 \mathrm{~min}$ annealing at $37^{\circ} \mathrm{C}$ ), followed by two cycles with the annealing temperature at $41^{\circ} \mathrm{C}$. The amplification was continued for 26 cycles using an annealing temperature of $45^{\circ} \mathrm{C}$. The resulting amplification products were separated on a $2 \%(\mathrm{w} / \mathrm{v})$ agarose gel. The smear containing the amplified DNA was isolated from the gel using the QiaEx gel extraction kit (Qiagen, Chatsworth, CA, USA), and subjected to 30 cycles of DNA amplification $\left(1 \mathrm{~min}\right.$ denaturation at $95^{\circ} \mathrm{C}, 2 \mathrm{~min}$ annealing at $45^{\circ} \mathrm{C}, 2$ min primer extension at $72^{\circ} \mathrm{C}$ ). The resulting product was blunt-ended with Klenow fragment of $E$. coli DNA polymerase I and T4 DNA polymerase (Boehringer), and ligated to pBluescript-KS (Stratagene) that was treated with SmaI and calf intestinal phosphatase (Boehringer). Ninety insert-containing clones were picked. Clones were tested for FSH and androgen induction by hybridisation to Northern blots containing total
RNA isolated from 21-day-old Sertoli cells, cultured for $4 \mathrm{~h}$ or $24 \mathrm{~h}$ in the presence of FSH or the synthetic androgen R1881 (NEN). One of the clones was found to be stimulated by FSH but not by androgens. This clone was used to screen the Sertoli cell cDNA library, and three cDNA clones were isolated. The largest insert was rescued according to the protocol supplied by the supplier (Stratagene). For sequencing the IRPRI cDNA clone, partial overlapping clones were obtained by ExollI nuclease deletion using the Erase-a-base method (Promega, Madison, WI, USA). The subclones were sequenced by the dideoxy chain termination method (Sanger et al., 1977) in both orientations, using T7 DNA polymerase (Pharmacia, Uppsala, Sweden). After sequencing LRPRI, database analysis was performed using the program suite of the University of Wisconsin Genetics Computer Group (Devereux, 1992).

\subsection{In vitro transcription and translation}

For in vitro transcription, the $L R P R I$ plasmid was linearized using $X h o I$. Then, the linearized plasmid was purified and treated with proteinase $K$ as described by Sambrook (1989). A second purification step was performed by extraction with phenol/chloroform and precipitation with ethanol. An amount of $500 \mathrm{ng}$ of linearized $L R P R I$ plasmid was added to $20 \mathrm{U}$ RNasin (Promega), $0.4 \mathrm{mM}$ rUTP, rGTP, rATP and rCTP (Pharmacia), $30 \mathrm{mM}$ dithiothreitol, $25 \mathrm{U} \mathrm{T}_{3}$ RNA polymerase (Statagene) and $1 \times$ transcription buffer $(40 \mathrm{mM}$ Tris, $50 \mathrm{mM} \mathrm{NaCl}, 8 \mathrm{mM}$ $\mathrm{MgCl}_{2}$ and $2 \mathrm{mM}$ spermidine; Stratagene) in a total volume of $25 \mu \mathrm{l}$. Transcription was carried out at $37^{\circ} \mathrm{C}$ for $1 \mathrm{~h}$. Subsequently, $10 \mathrm{U}$ of RNase-free DNase I (Stratagene) was added, and DNA digestion took place for $30 \mathrm{~min}$ at $37^{\circ} \mathrm{C}$. The RNA was purified by phenol/chloroform extraction, precipitated with ethanol and dissolved in $10 \mu \mathrm{l}$ RNase-free $\mathrm{H}_{2} \mathrm{O}$. A $10 \%$ portion of this RNA was used for in vitro translation in the presence of $\left[{ }^{35} \mathrm{~S}\right]-$ methionine, which was performed by using the rabbit reticulocyte lysate system (Promega). The translation products were separated by SDS-PAGE ( $7 \%$ w/v acrylamide separating gel, $4 \% \mathrm{w} / \mathrm{v}$ acrylamide stacking gel) (Laemli, 1970). After electrophoresis, the gel was fixed and dried. Autoradiography was performed to visualize the bands.

\section{Results}

\subsection{Cloning and characterization of LRPRI}

Using a DNA amplification approach, we isolated LRPRI from a Sertoli cell cDNA library. This cDNA clone represents a mRNA, of which expression in Sertoli cells is rapidly induced by FSH. Sequence analysis (Fig. 1) showed that the largest cDNA clone has a length of $3108 \mathrm{bp}$. The zinc-finger primer sequence, used to amplify the DNA, can be found at position 2195 . However, only 19 out of the 27 nucleotides in the primer can be 


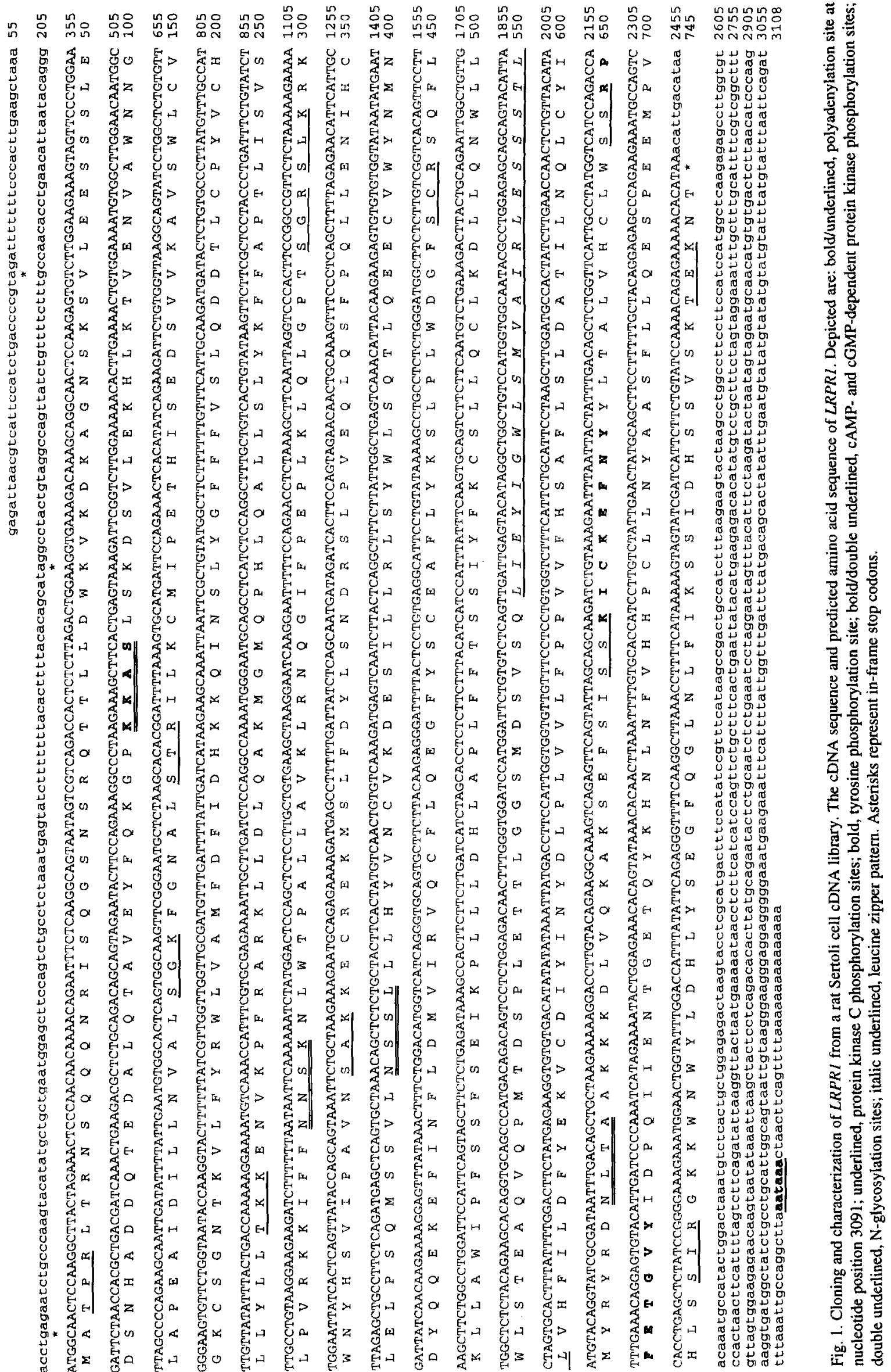


found in the LRPRI cDNA sequence. These nucleotides encode an amino acid sequence in which 4 out of the 9 amino acids of the $\mathrm{C}_{2} \mathrm{H}_{2}$ zinc finger connecting peptide (Thiessen, 1990) are present. Neither the N-terminal cysteines nor the $\mathrm{C}$-terminal histidines can be found. This agrees with the absence of a $\mathrm{C}_{2} \mathrm{H}_{2}$ zinc finger in the LRPR1 protein sequence. The longest open reading frame encodes a protein of 746 amino acid residues and a relative molecular mass of $85.6 \mathrm{kDa}$. The $3^{\prime}$ untranslated region has a length of $670 \mathrm{bp}$ and contains a canonical polyadenylation site at position 3074 .

The first in frame ATG is present at position 206 of the total length of the clone. This translation start site was compared to the Kozak consensus sequence for initiation of translation in vertebrates [GCC(A/G)CCATGG] (Kozak, 1987, 1989). Positions -3 (three nucleotides upstream from the ATG codon) and +4 , which are considered to be the most discriminating nucleotides in the Kozak consensus sequence for translation start sites (Kozak, 1987, 1989), conform with this consensus, whereas the other nucleotides differ. Higher similarity (nucleotides at positions -1 and -2 incorrect) with the Kozak consensus sequence was found at the ATG codon at position 881. In vitro transcription of the LRPRI cDNA, followed by in vitro translation, revealed that both translation start sites are operational in a cell-free system. Two major and some minor protein bands were visible on a polyacrylamide gel after in vitro translation (Fig. 2). The size of the upper band conforms with the expected molecular mass of $85.6 \mathrm{kDa}$. The lower band with a molecular mass of approximately $60 \mathrm{kDa}$ can be explained by secondary starts at the AUG at position 881 .

Comparison of nucleotide and amino acid sequences to the EMBL and GenBank databases revealed only one entry with significant homology (Fig. 3). This homologous sequence, EST00443, which was randomly chosen from a human cDNA library as an expressed sequence tag (Adams et al., 1992), shows $80.6 \%$ and $74.0 \%$ identity with LRPR1 at the nucleotide and amino acid levels, respectively. No further information on EST00443 is available.

Several small protein sequence motifs can be found in LRPR1. Consensus $\mathrm{N}$-glycosylation sites are located at amino acid residues 260,362 and 607. Also, one cAMP/ cGMP-dependent protein kinase phosphorylation site, several protein kinase $C$ phosphorylation sites, and two tyrosine kinase phosphorylation sites were identified (Fig. 1). A leucine zipper pattern was found at position 530 of the protein sequence. This protein-protein interaction domain is present in many gene regulatory proteins, such as the cAMP responsive element binding proteins (CREBP family), transcription factors of the AP1 family, and myc proto-oncogenes (Landschulz et al., 1988; O'Shea et al., 1989; Busch and Sassone-Corsi, 1990). The protein encoded by $L R P R I$ is leucine-rich; $16 \%$ of the amino acid residues is leucine.

\subsection{Hormonal and developmental control of LRPRI expression}

To study hormonal control of LRPRI mRNA expression in Sertoli cells, the isolated cells were pre-incubated for 3 days (see Section 2), and then treated for $4 \mathrm{~h}$ with increasing doses of FSH. Northern blot analysis of total RNA isolated from these Sertoli cells, using a LRPRI cDNA probe, revealed a rapidly responding $4 \mathrm{~kb}$ mRNA that is induced by FSH. This action of FSH occurs through the cAMP transduction pathway, as indicated by the response in cells treated with either $0.5 \mathrm{mM}$

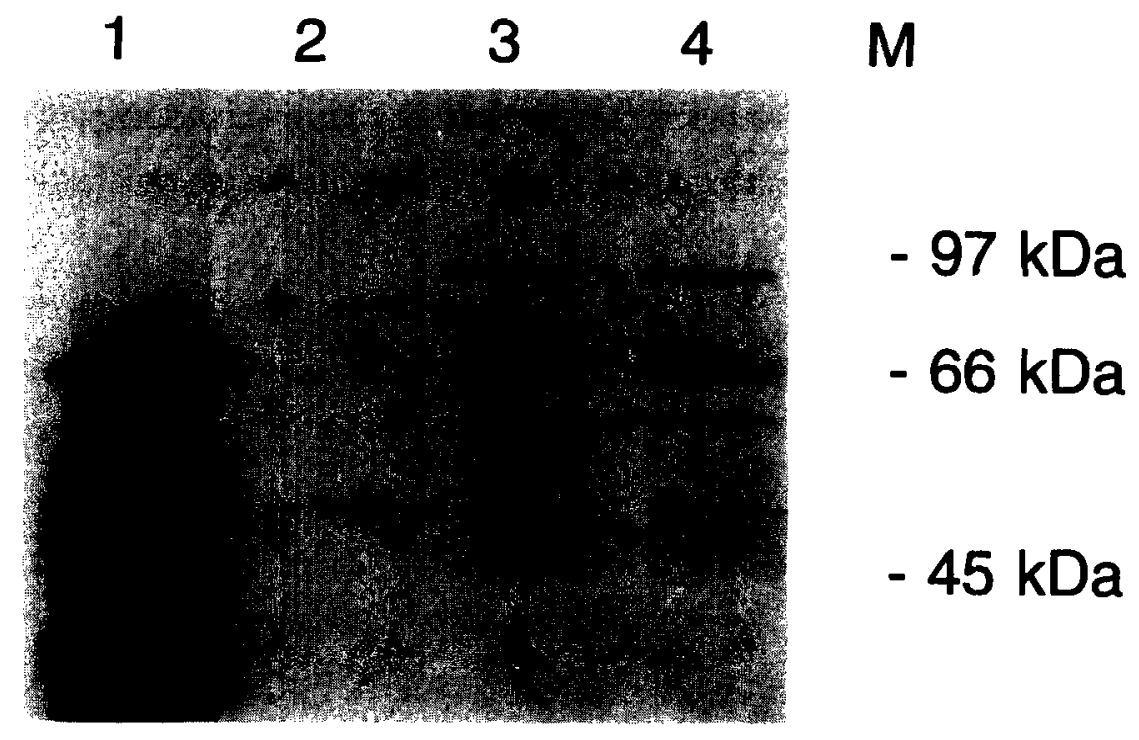

Fig. 2. Autoradiogram of the in vitro transcription/translation assay. The in vitro translation assay was performed as described in Section 2 , with addition of luciferase mRNA (positive control, lane 1), no RNA (negative control, lane 2) or LRPRI mRNA obtained by 2 independent in vitro transcription procedures (lanes 3 and 4). 
r.

$1574 \quad 1633$

LRPR1 CCATTCAGTAGCTTCTCTGAGATAAAGCCACTTCTTCTTGATCATCTAGCACCTCTCTTC

EST00443 CCTTTTAGTAGCTTCTCTGAGGTGAAACCACTTCTTTTTGACCATCTAGCGCANTCTNTC 1

1693

LRPRI TTTACATCATCCATTTATTTCAAGTGCAGTCTTCTTCAATGTCTGAAAGÁCTTACTGCAG

EST00443 TTTACATCAACCATTTATTTCAAGTGTAGTGTGCTTCAGAGTCTGAAAGAGCTATTGCAG

ERPR1 AATTGGCTGTTGTGGCTCTCTACAGAAGCACAGGTGCAGCCCATGACAGACAGTCCTCTG

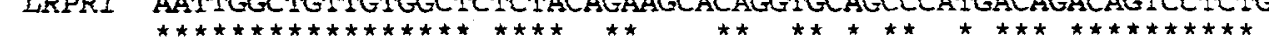

EST00443 AATTGGCTGTTGTGGCTTTCTATGGACATTCACATGAAACCTGTTACAAACAGTCCTCTA

LRPR1 GAGACAACTTTGGGTGGATCCATGGATTCTGTGTCTCAGTTGATTGAGTÁCATAGGCTGG

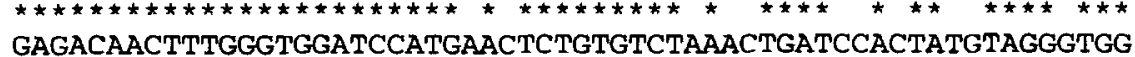

240

LRPR1 CTGTCCATGGTGGCAATACGCCTGGAGAGCAGCAGTACATTACTAGTGCACTTTATTTTG

EST00443 CTATCCACTACTGCAATGCGCTTGGAGAGCAACAATACTTTCTTGCTGCACTTTATTTTG

300

LRPR1 GACTTCTATGAGAAGGTGTGTGACATATATATAAATTATGACCTTCCATTGGTGGTGTTG EST00443 GATTTCTATGAGAAGGTGTGGACATATATATAAATNATAACCTTCCATTAGTGGGTATT
. . .

LRPR1 TTT.CCTCCTGTG.GTCTTTCATT.CTGCATTCCTAAGCTTGGATG

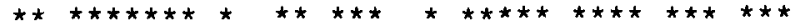

EST00443 GTTTCCTCCTGGGGATCCTTCTATTCTGCACTCCTCAGCCTGGG

II.

$457 \quad 516$

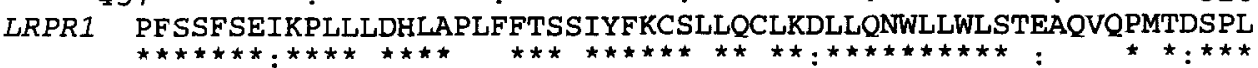

EST00443 PFSSFSEVKPLLFDELAXSXFTSTIYEKCSVLQSLKELLQNWLLWLSMDIFMKPUTNSPZ 1

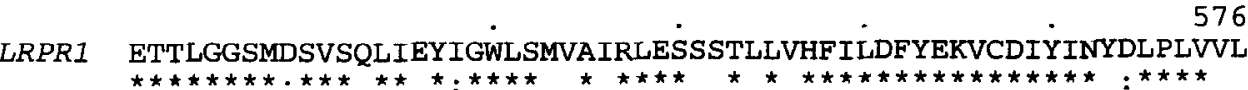

EST00443 ETTLGGSMNSVSKLIHYVGWLSTTAMRLESNNTFLLHF ILDFYEKVCDIYINXNLPLVGI

LRPRI FPP.VVFHSAFLSLDAT

EST00443 VSSWGSFYSALLSL

. 134

Fig. 3. Comparison of DNA sequence (I) and amino acid sequence (II) of $L R P R 1$ with those of the expressed sequence tag EST00443, isolated from a human brain cDNA library (Adams et al., 1992). Asterisks indicate identity between the two sequences. In the protein sequence comparison. nonidentical positions are indicated by a colon. 


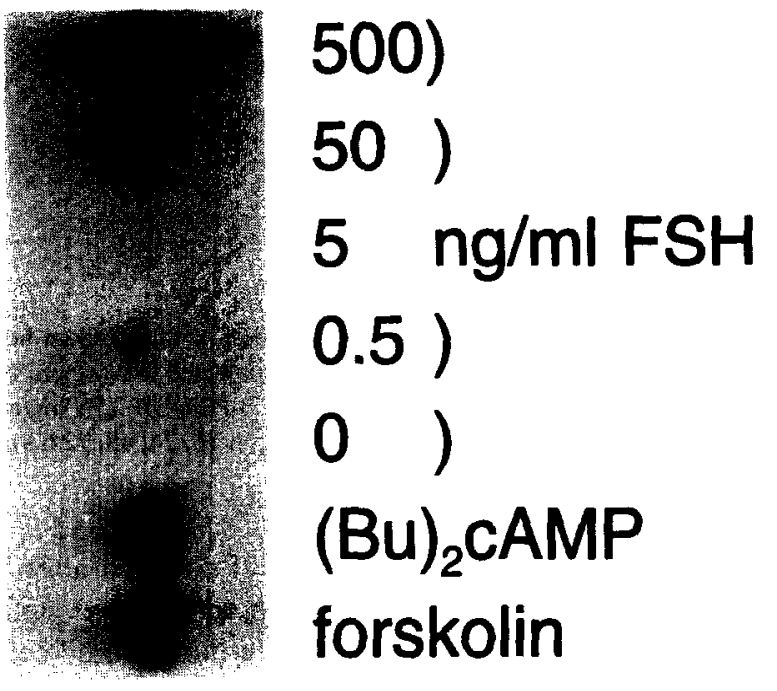

Fig. 4. Effect of FSH, forskolin and $(\mathrm{Bu})_{2}$ cAMP on LRPR1 mRNA expression in rat Sertoli cells. Sertoli cells were isolated from 21-dayold rats, cultured for 3 days without FSH (see Section 2), and then incuhated in the presence of o-FSH-S $16(0,0.5,5,50$ or $500 \mathrm{ng} / \mathrm{ml})$, forskolin $(20 \mu \mathrm{M})$, or $(\mathrm{Bu})_{2}$ cAMP $(0.5 \mathrm{mM})$, for $4 \mathrm{~h}$. Total RNA (20 $\mu \mathrm{g} / \mathrm{lane})$ was isolated and subjected to Northern blot analysis using an $L R P R I$ cDNA probe.

$(\mathrm{Bu})_{2} \mathrm{cAMP}$ or $20 \mu \mathrm{M}$ forskolin (Fig. 4). FSH induces $L R P R I$ mRNA expression in a dose-dependent manner, with an $\mathrm{ED}_{50}$ between 5 and $50 \mathrm{ng} / \mathrm{ml}$ ovine-FSH-S16. Similar FSH dose-response relationships have been reported for other parameters of Sertoli cells using this PSH preparation (Themmen et al., 1991).

To study the specificity of the effect of FSH on LRPRI mRNA expression, Sertoli cells were, after a 3-day period of pre-incubation, treated for $4 \mathrm{~h}$ with several other agents $(0.1 \mathrm{ng} / \mathrm{ml}$ and $100 \mathrm{ng} / \mathrm{ml}$ IGF-I, $0.5 \mathrm{ng} / \mathrm{ml}$ and $5 \mu \mathrm{g} / \mathrm{ml}$ insulin, $10^{-8} \mathrm{M} \mathrm{R} 1881,10^{-8} \mathrm{M}$ PMA, or $10^{-8} \mathrm{M} \mathrm{PA}$ ), and

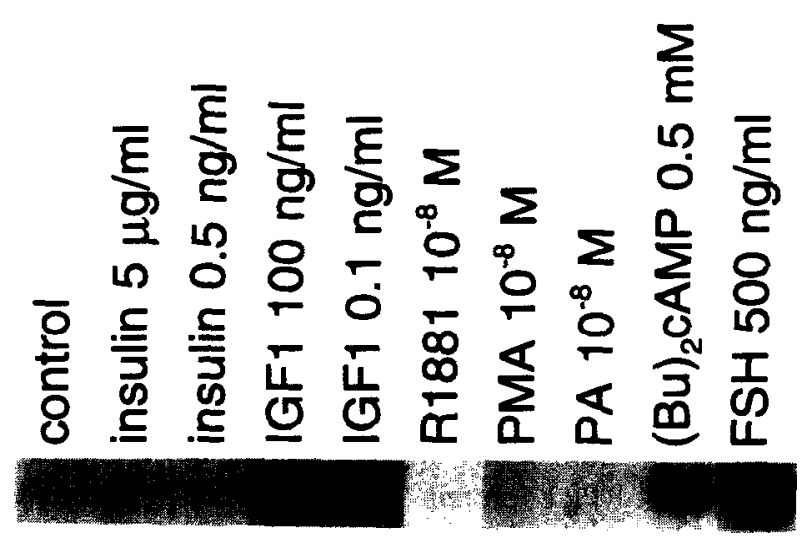

Fig. 5. LRPRI mRNA expression in rat Sertoli cells is specifically regulated by FSH. Sertoli cells were isolated from 21-day-old rats, cultured for 3 days without FSH, and then incubated in the presence of insulin $(0.5 \mathrm{ng} / \mathrm{ml}$ or $5 \mu \mathrm{g} / \mathrm{ml})$, IGF-1 $(0.1 \mathrm{ng} / \mathrm{ml}$ or $100 \mathrm{ng} / \mathrm{ml}), \mathrm{R} 1881$ $\left(10^{-8} \mathrm{M}\right)$, PMA $\left(10^{-8} \mathrm{M}\right), \mathrm{PA}\left(10^{-8} \mathrm{M}\right),(\mathrm{Bu})_{2} \mathrm{cAMP}(0.5 \mathrm{mM})$ or FSH $(500 \mathrm{ng} / \mathrm{ml})$, for $4 \mathrm{~h}$. Total RNA ( $20 \mu \mathrm{g} / \mathrm{lane})$ was isolated and subjected to Northern blot analysis using an $L R P R I$ cDNA probe.

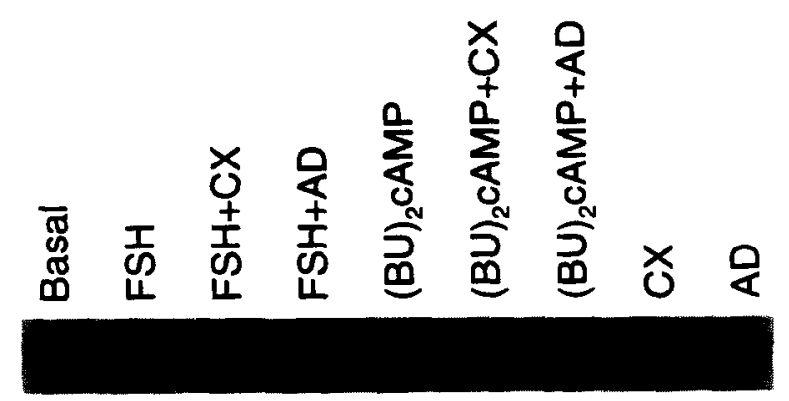

Fig. 6. Effects of cycloheximide and actinomycin D on LRPRI mRNA expression. Sertoli cells were isolated from 21-day-old rats, cultured for 3 days without $\mathrm{FSH}$, and then pre-incubated with or without actinomycin $\mathrm{D}(\mathrm{AD}, 5 \mu \mathrm{g} / \mathrm{ml})$ or cycloheximide $(\mathrm{CX}, 50 \mu \mathrm{g} / \mathrm{ml})$, for $30 \mathrm{~min}$. Subsequently, the cells were incubated in the presence or absence of $\mathrm{o}$ FSH-S16 $(500 \mathrm{ng} / \mathrm{ml})$ or $(\mathrm{Bu})_{2} \mathrm{cAMP}(0.5 \mathrm{mM})$, for $4 \mathrm{~h}$. Total RNA ( $5 \mu \mathrm{g} / \mathrm{lane}$ ) was isolated and subjected to RNase protection analysis using an $L R P R I$ anti-sense RNA probe. An anti-sense GAPDH probe was used to assure the intactness of the loaded RNA.

with $0.5 \mathrm{mM}(\mathrm{Bu})_{2} \mathrm{cAMP}$ and $500 \mathrm{ng} / \mathrm{ml} \mathrm{FSH}$. None of the tested hormones and growth factors, besides FSH (and $(\mathrm{Bu})_{2} \mathrm{cAMP}$ ), were found to exert an effect on $L R P R I$ mRNA expression (Fig. 5). Thus, the available data indicate that LRPRI mRNA expression, under the present conditions, is specifically regulated by FSH.

FSH induction of LRPR1 mRNA expression was inhibited by treating Sertoli cells with the transcription inhibitor actinomycin D $(5 \mu \mathrm{g} / \mathrm{ml})$, but was not inhibited when FSH was added in the presence of the protein synthesis inhibitor cycloheximide $(50 \mu \mathrm{g} / \mathrm{ml})$ (Fig. 6). This indicates that $L R P R I$ mRNA expression is transcriptionally regulated by FSH, through a direct mechanism which is independent of de novo protein synthesis. In the RNase protection assay not only the specific $322 \mathrm{bp}$ protected fragment was found, but also some less abundant nonspecific bands which are due to incomplete breakdown of the probe.

LRPRI mRNA was not found in isolated cell preparations of pachytene spermatocytes, round spermatids or peritubular myoied cells (results not shown). However, LRPRI mRNA expression is not limited to the testis.

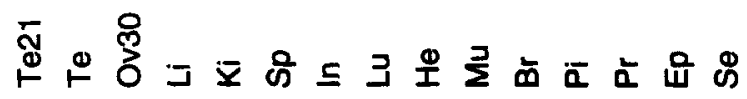

Fig. 7. Tissue specificity of $L R P R I$ mRNA expression. Total RNA ( $20 \mu \mathrm{g} / \mathrm{lane}$ ) from different tissues was isolated and subjected to Northern blot analysis using an $L R P R I$ cDNA probe. Abbreviations: Te21, testis of 21-day-old rat; Te, testis of adult rat; Ov30, ovary of 30 dayold-rat; Li, liver; Sp, spleen; In, intestine; Lu, lung; He, heart; Mu, muscle; $\mathrm{Br}$, brain; $\mathrm{Pi}$, pituitary gland; $\mathrm{Pr}$, prostate; Ep, epididymis; Se, seminal vesicle (non-gonadal tissues were from adult rats). 

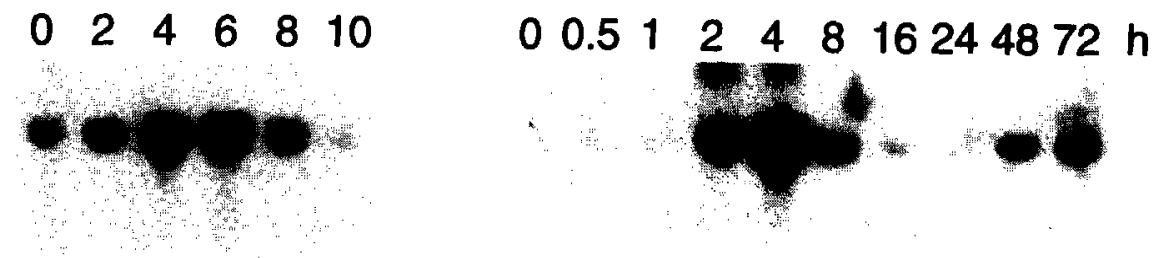

Fig. 8. Effect of FSH on LRPRI mRNA expression in vivo and in vitro. Left: 21 -day-old rats were injected i.p. with o-FSH-S16 ( $\mu$ g/ gram body weight) and sacrificed at different time points $(0,2,4,6,8 \mathrm{~h})$ after injection. Total testis RNA (20 $\mu \mathrm{g} / \mathrm{lane})$ was isolated and subjected to Northern blot analysis using an LRPRI cDNA probe. Right: Sertoli cells isolated from 21-day-old rats were incubated in the presence of o-FSH-S16 (500 ng/ml), following 3 days of culture without FSH. Total RNA was isolated at different time points after addition of FSH $(0,0.5,1,2,4,8,16,24,48,72 \mathrm{~h})$, and subjected to Northern blot analysis as described for the left panel.

Relatively low expression levels were found in spleen, ovary, lung, and in brain tissue (Fig. 7).

To investigate FSH effects on LRPR1 mRNA expression in vivo, intact 21-day-old rats were treated with FSH (single i.p. injection), and testicular $L R P R I$ mRNA expression was measured at several time points after this injection, using Northern analysis of total testicular RNA (Fig. 7). There is a considerable basal level of testicular $L R P R I \mathrm{mRNA}$ expression in intact rats, whereas the basal level of LRPRI mRNA expression in Sertoli cells after 3 days of culture in the absence of FSH was very low (Fig. 8). It was observed that testicular LRPRI mRNA expression in these immature rats was very rapidly increased by administration of exogenous FSH. A notable increase in testicular $L R P R 1 \mathrm{mRNA}$ expression can first be seen at $2 \mathrm{~h}$ after injection, with a maximal effect at $4 \mathrm{~h}$ (Fig. 8). This is similar to the time course of LRPRI mRNA induction that was observed using isolated Sertoli cells (Fig. 8).

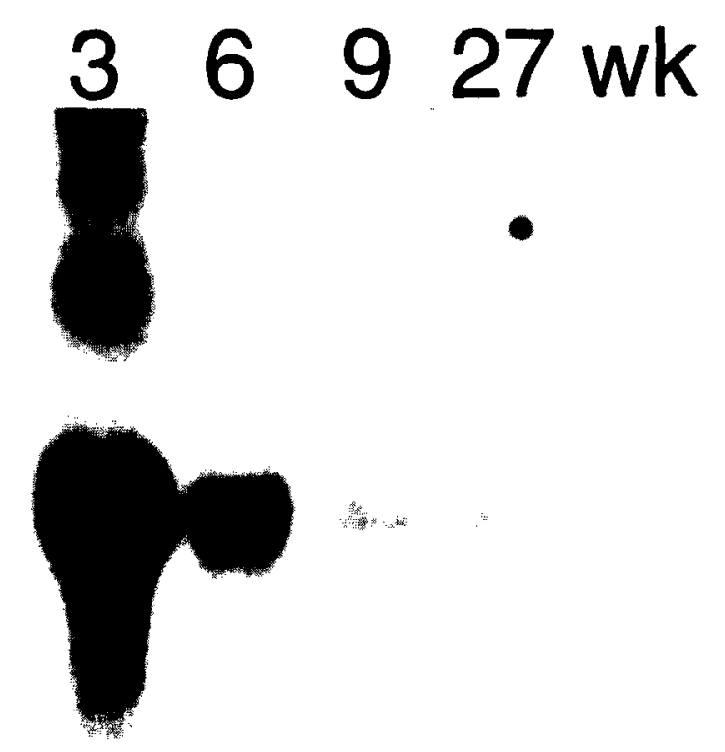

Fig. 9. Testicular mRNA expression of $L R P R I$ at different ages. Total testis RNA ( $20 \mu \mathrm{g} / \mathrm{lane})$ was isolated from rats at 3, 6, 9 and 27 weeks of age, and subjected to Northem blot analysis using an LRPRI cDNA probe.
The LRPRI mRNA expression level declined after 8$16 \mathrm{~h}$ of FSH stimulation, both in vitro and in vivo, and a very low level was found after $24 \mathrm{~h}$. In the cultured cells, $L R P R I$ mRNA expression reappeared $48 \mathrm{~h}$ after addition of FSH. These later time-points were not tested in the in vivo experiment, where only a single FSH injection was given, which probably will not result in a long-term increased level of circulating FSH.

Maturation of Sertoli cells, and different interactions with the developing germ cells, may have pronounced effects on expression of various genes in Sertoli cells (Pineau et al., 1990). Therefore we measured LRPRI mRNA expression in testes from rats of 3, 6, 9 and 27 weeks old, i.e. during and after the initiation of spermatogenesis (Fig. 9). A marked decrease in LRPRI mRNA expression was observed during testis development. The fact that pachytene spermatocytes and spermatids do not express $L R P R I$ mRNA, may explain that the relative level of testicular expression of $L R P R I \mathrm{mRNA}$ declines with the appearance of increasing numbers of the more advanced germ cell types. However, it cannot be excluded that adult Sertoli cells have a lower level of LRPRI mRNA expression compared to immature Sertoli cells.

\section{Discussion}

We cloned and characterized LRPRI, a cDNA clone which encodes a leucine-rich protein with a molecular mass of $85.6 \mathrm{kDa}$. Database analysis did not reveal significant homology to proteins with known functions, but gave somc information on specific motifs that are present in the LRPR1 protein sequence, such as a leucine zipper and possible phosphorylation sites. However, neither a nuclear localization signal nor a signal sequence is present in the LRPR1 protein sequence, indicating that LRPR1 will not be transported over the nuclear envelope or excreted by the cell. Thus, LRPR 1 might be located in the cytoplasm.

LRPRI mRNA expression is highest in testis, although the mRNA can also be found in ovary, lung, spleen and brain. Little can yet be learned about the function of LRPR I protein from the expression of $L R P R 1 \mathrm{mRNA}$ in 
these different tissues, but more information on LRPR1 function may be obtained when LRPR1 antibodies have been developed that can be used for (sub)cellular localization studies.

In Sertoli cells, the LRPRI mRNA expression level was found to be rapidly and dose-dependently upregulated by FSH through the cAMP pathway. Furthermore, the present results indicate that this up-regulation involves a direct mechanism at the transcriptional level, which does not require FSH-induced de novo synthesis of other gene regulatory proteins.

LRPRI mRNA expression in cultured Sertoli cells from immature rats is, under the present conditions, upregulated by FSH but not influenced by the other hormones and growth factors which we have tested. This indicates that $L R P R I$ mRNA expression might be specifically regulated by FSH. However, effects of other agents on LRPRI mRNA expression in cultured Sertoli cells, under various conditions, remain to be investigated.

The temporal pattern of FSH regulation of $L R P R l$ mRNA expression is quite similar in both the in vitro and in vivo situations. However, the basal LRPRI mRNA level is higher in vivo than it is in cultured Sertoli cells, probably because the cultured cells have not been exposed to FSH for 3 days, whereas a basal level of $L R P R I$ mRNA expression in vivo will be maintained by circulating FSH. After the rapid induction of LRPRI mRNA expression by addition of FSH to cultured Sertoli cells, expression declined to control levels during $16 \mathrm{~h}$ of incubation in the continuous presence of FSH, followed by longterm up-regulation $(48 \mathrm{~h})$, which indicates that the Sertoli cells reach a new steady state. In the intact animal, after the increase of testicular $L R P R I$ mRNA expression as a response to a single FSH injection, down-regulation of this mRNA expression below the basal level was also observed.

Transient up-regulation of $L R P R I$ mRNA expression followed by down-regulation may be the result of a loss of sensitivity of the Sertoli cells to FSH. Loss of responsiveness can be caused by ligand-induced downregulation of FSH receptor mRNA and protein (Themmen et al., 1991), in combination with other mechanisms causing desensitization (Zhang et al., 1991; Benovic et al., 1987).

The observation that the in vivo temporal pattern of regulation of $L R P R I$ mRNA expression is similar to the in vitro pattern, indicates the usefulness of studying the molecular mechanism of the regulation of $L R P R I$ mRNA expression by FSH.

According to criteria described by Roesler et al. (1988), concerning genes of which transcription is induced by cAMP, two general categories can be postulated. Group 1 genes are rapidly regulated by cAMP, whereas transcription of genes in Group 2 is increased only after several hours of increased cAMP levels. Also, in most cases, cAMP induction of the genes in Group 1 is cycloheximide insensitive. The action of FSH on LRPR1 mRNA expression indicates that the LRPR1 gene falls into Group 1 of this classification. This is also true for the c-fos and $\alpha$-inhibin genes. The c-fos, $\alpha$ inhibin and LRPRI mRNA levels in Sertoli cells are rapidly up-regulated by FSH, and in all cases no inhibition of mRNA expression was seen when translation was inhibited by cycloheximide (Hall et al., 1988; Klaij et al., 1990).

In the promoters of both the $\mathrm{c}$-fos and $\alpha$-inhibin genes, cAMP responsive elements (CREs) have been identified (Muller, 1986; Pei et al., 1991). Since the LRPRI gene can be compared to the c-fos and $\alpha$-inhibin genes with respect to the response to FSH/cAMP, it is very possible that one or more CREs are also present in the LRPRI gene promoter. We are currently characterizing the promoter of the LRPRI gene, to study the DNA sequences that are involved in regulation of LRPRI mRNA expression by FSH, and also to use the promoter in combination with a reporter gene in in vitro studies of FSH action. Moreover, $L R P R I$ could prove to be a very useful parameter for evaluation of FSH action both in vivo and in vitro. Compared to c-fos, $L R P R I$ shows a response which is very specific for FSH. We have tested several agents (insulin, IGF-I, R1881, PMA and PA), but regulators of $L R P R I$ mRNA expression other than FSH have not yet been found. Furthermore, the Sertoli cell-specific $L R P R I$ mRNA expression responds more rapidly to FSH compared to other known FSH-regulated genes such as $\alpha$ inhibin, tissue type plasminogen activator and transferrin, which are found in many other cell types. Because of its sensitive, rapid and cell specific response, and the fact that FSH acts on LRPR1 expression both in vitro and in vivo, LRPR1 might be a very useful marker of FSH action.

In conclusion, we cloned and sequenced a cDNA, $L R P R I$, representing the so-called leucine-rich primary response gene-1, which encodes a leucine-rich protein with unknown function. $L R P R I \mathrm{mRNA}$ shows a relatively high expression in Sertoli cells, and its expression in these cells is very rapidly induced by FSH both in situ and in cell culture, through a primary response mechanism.

\section{Acknowledgements}

This work was supported by the Dutch Ministry of WVC (The Alternatives to Animal Experiments Platform) and the Dutch Research Council through GB-MW. Ovine FSH-S16 was provided by the NIH (Bethesda, MD, USA), and IGF-I was a kind gift of Dr. J. Foekens, Dr Daniel den Hoed Cancer Center, Rotterdan, The Netherlands. The authors wish to thank A. Verkerk (Department of Cell Biology, Erasmus University Rotterdam, Rotterdam, The Netherlands) for the development and maintenance of the RNA-DNA-protein analysis software. 


\section{References}

Adams, M.D., Dubnick, M., Kerlavage, A.R., Moreno, R., Kelley, J.M., Utterback, T.R., Nagle, J.W., Fields, C. and Venter, J.C. (1992) Nature 355, 632-634.

Auffray, C. and Rougeon, F. (1980) Eur. J. Biochem. 107, 303-314.

Baarends, W.M., van Helmond, M.J.L., Post, M., van der Schoot, P.J.C.M., Hoogerbrugge, J.W., de Winter, J.P., Uilenbroek, J.T.J., Karels, B., Wilming, L.G., Meijers, J.H.C., Themmen, A.P.N. and Grootegoed, J.A. (1994) Development 120, 189-197.

Bardin, C.W., Cheng, C.Y., Mustow, N.A. and Gunsalus, G.L. (1994) in The Physiology of Reproduction, Second Edition (Knobil, E. and Neill, J.D., eds.), pp. 1291-1333, Raven Press, New York.

Benovic, J.L., Kühn, H., Weyand, I., Codina, J., Caron, M.G. and Lefkowitz, R.J. (1987) Proc. Natl. Acad. Sci. USA 84, 8879-8882.

Busch, S.J. and Sassone-Corsi, P. (1990) Trends Genet. 6, 36-40.

Clermont, Y. and Harvey, S.C. (1967) in Ciba Foundation Colloquia on Endocrinology, Vol 16 (Churchill, J. ed.), pp. 173-189.

Devereux, J. (1992) The GCG sequence analysis software package, Version 7.1 Genetics Computer Group Inc. Univ. Res. Park, Madison, WI, USA.

Dorrington, J.H., Roller, N.F. and Fritz, I.B. (1975) Mol. Cell. Endocrinol. 3, 57-70.

Fort, Ph., Marty, L., Piechaczyk, M., El Sabrouty, S., Dani, Ch., Jeanteur, Ph. and Blanchard, J.M. (1985) Nucleic Acids. Res. 13, 14311442.

Hagenas, L., Ritzen, E.M., Ploen, L., Hansson, V., French, F.S. and Nayfeh, S.N. (1975) Mol. Cell. Endocrinol. 2, 339-350.

Hall, S.H., Joseph, D.R., French, F.S. and Conti, M. (1988) Mol. Endocrinol. 2, 55-61.

Hansson, V., Weddington, S.C., McLean, W.S., Smith, A.A., Nayfeh, S.N., French, F.S. and Ritzen, E.M. (1975a) J. Reprod. Fertil. 44, 363-375.

Hansson, V., Weddington, S.C., Petrusz, P., Ritzen, E.M., Nayfeh, S.N. and French, F.S. (1975b) Endocrinology 97, 469-473.

Huggenvik, J.I., Idzerda, R.L., Haywood, L., Lee, D.C., McKnight, G.S. and Griswold, M.D. (1987) Endocrinology 120, 332-340.

Klaij, I.A., Toebosch, A.M.W., Themmen, A.P.N., Shimasaki, S., de Jong. F.J. and Grootegoed, J.A. (1990) Mol. Cell. Endocrinol. 68, 45-52.

Kozak, M. (1987) Nucleic Acids Res. 20, 8125-8132.

Kozak, M. (1989) J. Cell. Biol. 108, 229-241.

Landschulz, W.H., Johnson, P.F. and McKnight, S.L. (1988) Science
240, 1759-1764.

Laemli, U.K. (1970) Nature 227, 680-685.

Marshall, G.R., Jockenhövel, F., Lüdecke, D. and Nieschlag, E. (1986) Acta Endocrinol. 113, 424-431.

Means, A.R., Fakunding, J.L., Huckins, C., Tindall, D.J. and Vitale, R. (1976) Rec. Prog. Horm. Res. 32, 477-522.

Moudgal, N.R., Ravindranath, N., Murthy, G.S., Dighe, R.R., Aravindan, G.R. and Martin, F. (1992) J. Reprod. Fertil. 96, 91-102.

Muller, R. (1986) Biochim. Biophys. Acta 823, 207-225.

Nargolwalla, C., McCabe, D. and Fritz, I.B. (1990) Mol. Cell. Endocrinol. 70, 73-80.

Norton, J.N. and Skinner, M.K. (1992) Mol. Endocrinol. 6, 2018-2026.

O'Shea, E.K., Rutkowski, R. and Kim, P.S. (1989) Science 243, 538542.

Pei, L., Dodson, R., Schoderbek, W.E., Maurer, R.A. and Mayo, K.E. (1991) Mol. Endocrinol. 5, 521-534.

Pineau, C., Sharpe, R.M., Saunders, P.T., Gerard, N. and Jegou, B. (1990) Mol. Cell. Endocrinol. 72, 13-22.

Reventos, J., Hammond, G.L., Crozat, A., Brooks, D.E., Gunsalus, G.L., Bardin, C.W. and Musto, N.A. (1988) Mol. Endocrinol. 2, 125-132.

Roesler, W.J., Vandenbark, G.R. and Hanson, R.W. (1988) J. Biol. Chem. 263, 9063-9066.

Rossi, P., Dolci, S., Albanesi, C., Grimaldi, P., Ricca, R. and Geremia, R. (1993) Dev. Biol. 155, 68-74.

Sambrook, J., Fritsch, E.F. and Maniatis, T. (1989) Molecular Cloning: A Laboratory Manual, 2nd edn., Cold Spring Harbor Laboratory Press, Cold Spring Harbor, NY.

Sanger, F., Nicklen, S. and Coulson, A.R. (1977) Proc. Natl. Acad. Sci. USA 74, 5463.

Smith, E.P., Hall, S.H., Monaco, L., French, F.S., Wilson, E.M. and Conti, M. (1989) Ann. N. Y. Acad. Sci. 564, 132-139.

Steinberger, E. (1971) Physiol. Rev. 51, 1-22.

Themmen, A.P.N., Blok, L.J., Post, M., Baarends, W.M., Hoogerbrugge, J.W., Parmentier, M., Vassart, G. and Grootegoed, J.A. (1991) Mol. Cell. Endocrinol. 78, R7-R13.

Thiesen, H.J. (1990) New Biol. 2, 363-374.

Toebosch, A.M.W., Robertson, D.M., Trapman, J., Klaassen, P., de Paus, R.A., de Jong, F.H. and Grootegoed, J.A. (1988) Mol. Cell. Endocrinol. 55, 101-105.

Toebosch, A.M.W., Robertson, D.M., Klaij, I.A., de Jong, F.H. and Grootegoed, J.A. (1989) J. Endocrinol. 122, 757-762.

Zhang, S., Dattatreyamurty, B. and Reichert, L.E. (1991) Endocrinology $128,295-302$ 